Original Research Paper

\title{
Pelatihan Pengolahan Sampah berbasis Masyarakat sebagai Alternatif Penanganan Limbah di Desa Penimbung
}

\author{
Immy Suci Rohyani ${ }^{1}$, Komang Satria Wirawan Rusady ${ }^{2}$, Muhammad Hafizzudin ${ }^{3}$, Dania Juliani ${ }^{4}$, Ni \\ Wayan Yusvika Yanti ${ }^{3}$, Baiq Karina Permatasari ${ }^{2}$, Ratih Ratna Putri ${ }^{2}$, Luthfiana Safhira Avanda, \\ Fatma Hardianti Sangian ${ }^{2}$, Ni Luh Wulan Sri Apsari ${ }^{2}$, Ni Kadek Sri Wulandari ${ }^{2}$, Wanda Yuliandini', \\ Elinda Sari ${ }^{2}$, Dita Dwi Angraeni ${ }^{6}$, Iin Marya Rizka ${ }^{7}$, Baiq Mia Rosdiana ${ }^{3}$ \\ ${ }^{I}$ Program Studi Ilmu Lingkungan, Fakultas Matematika dan Ilmu Pengetahuan Alam, Universitas Mataram, Mataram, \\ Indonesia \\ ${ }^{2}$ Program Studi Ilmu Hukum, Fakultas Hukum, Universitas Mataram, Mataram, Indonesia \\ ${ }^{3}$ Program Studi Akuntansi, Fakultas Ekonomi dan Bisnis, Universitas Mataram, Mataram, Indonesia \\ ${ }^{4}$ Program Studi Hubungan Internasional, Fakultas Ilmu Sosial dan Ilmu Politik, Universitas Mataram, Mataram, Indonesia \\ ${ }^{5}$ Program Studi Agribisnis, Fakultas Pertanian, Universitas Mataram, Mataram, Indonesia \\ ${ }^{6}$ Program Studi Ilmu dan Teknologi Pangan, Fakultas Pertanian, Universitas Mataram, Mataram, Indonesia \\ ${ }^{7}$ Program Studi Sosiologi, Fakultas Ilmu Sosial dan Ilmu Politik, Universitas Mataram, Mataram, Indonesia
}

https://doi.org/10.29303/jpmpi.v3i2.1174

Sitasi: Rohyani, I. S., Rusady, K. S. W., Hafizzudin, M., Juliani, D., Yanti, N. W. Y., Permatasari, B. K., Putri, R. R., Avanda, L. S., Sangian, F. H., Apsari, N. L. W. S., Wulandari, N. K. S., Yuliandini, W., Sari, E., Angraeni, D. D., Rizka, I. M \& Rosdiana, B. M. (2021). Pelatihan Pengolahan Sampah berbasis Masyarakat sebagai Alternatif Penanganan Limbah di Desa Penimbung. Jurnal Pengabdian Magister Pendidikan IPA 4(4)

Article history

Received: 10 Oktober 2021

Revised: 30 Oktober 2021

Accepted: 17 November 2021

*Corresponding Author: Immy Suci Rohyani, Universitas Mataram;

Email:

kknpenimbung2021@gmail.com

\begin{abstract}
Desa penimbung merupakan salah satu desa di Kecamatan Gunung Sari, Lombok Barat. Desa penimbung khususnya warga dusun Penimbung Timur banyak melakukan pembuangan sampah disungai karena belum adanya fasilitas seperti TPS (Tempat Penampungan Sementara) dan mobil pengangkut sampah, sedangkan TPA (Tempat pembuangan akhir) berjarak lumayan jauh dari Desa tersebut. Tujuan dari program pengolahan sampah ini yaitu meningkatkan kesadaran masyarakat agar tidak membuang sampah di tempat yang sembarangan seperti sungai serta dapat berkontribusi dalam upaya mengurangi tumpukan sampah dan mengolah sampah menjadi produk yang bermanfaat. Metode yang digunakan dalam pelaksanaan program pengolahan sampah ini meliputi kegiatan sosialisasi tentang pengolahan sampah dilanjutkan dengan pelatihan pengolahan sampah organic secara langsung. Hasil yang diperoleh dari kegiatan pengolahan sampah ini berupa kompos Takakura dan ecobrik. Dengan adanya pelatihan ini masyarakat menjadi lebih memahami bahwa sampah dapat diolah kembali. Mereka sudah mulai melakukan pengolahan tersebut di rumah masing-masing terutama pengolahan sampah dapur berupa pembuatan kompos takakura.
\end{abstract}

Keywords: Sampah; Takakura; Ecobrick.

disungai karena belum adanya fasilitas seperti TPS (Tempat Penampungan Sementara) dan mobil pengangkut sampah yang menjadi wadah untuk warga membuang sampah, sedangkan TPA (Tempat pembuangan akhir) berjarak lumayan jauh dari Desa tersebut. Kurangnya fasilitas dan kesadaran masyarakat dalam upaya pembuangan sampah yang tepat dapat mengakibatkan berbagai macam implikasi baik secara langsung maupun 
tidak langsung. Pembuangan sampah pada sungai dapat menimbulkan berbagai macam resiko seperti pencemaran udara, tanah,air, menimbulkan berbagai macam penyakit, hingga terjadinya banjir. Oleh karena itu, perlunya meningkatkan kesadaran masyarakat agar dapat mengolah sampah menjadi produk yang bermanfaat sehingga dapat meminimalisir terjadinya pembuangan dan penumpukan sampah.

Pengolahan sampah dapat dibedakan menjadi 2 yaitu, pengolahan sampah organik dan anorganik. Sampah organik adalah sampah yang berasal dari sisa mahkluk hidup yang mudah terurai secara alami maupun dengan campur tangan manusia. Sampah organik ini didikotomikan menjadi dua jenis, yakni sampah organik kering dan sampah organik basah. Sampah Organik Basah memiliki karakteristik kandungan air yang cukup tinggi, jenis sampah organik ini mudah membusuk dan terurai secara alami karena kelembapannya yang tinggi. Misalnya seperti sampah rumah tangga yaitu sisa makanan, sayuran dan buah-buahan atau kotoran manusia dan hewan. Di sisi lain, sampah organik kering tidak memiliki kandungan air besar dan cenderung lebih lama terurainya dibanding sampah organik basah. Contohnya seperti daun-daun kering atau ranting pohon. sampah anorganik adalah sampah yang tidak mudah membusuk, dan umumnya bukan berasal dari tumbuhan dan hewan, seperti kaleng, botol kaca, plastik, kertas, maupun pembungkus makanan.

Salah satu cara dalam mengurangi timbunan sampah organik agar tidak mencemari tanah,air maupun udara adalah dengan cara pengomposan. Metode pengomposan merupakan salah satu cara mengolah sampah organik menjadi pupuk. Metode takakura merupakan satu metode pengomposan hasil penelitian seorang ahli bernama Mr. Koji Takakura dari Jepang. Proses pengomposan dengan metode takakura merupakan proses pengomposan aerob, dimana udara dibutuhkan sebagai asupan penting dalam proses pertumbuhan mikroorganisme yang menguraikan sampah menjadi kompos. Sedangkan sampah anorganik dapat diolah dengan metode ecobrik. Ecobrik sendiri merupakan salah satu metode pengolahan limbah sampah plastic menjadi barang serbaguna yang tergolong mudah. Berdasarkan hal tersebut, melalui program pengolahan sampah yang di inisiasi oleh kelompok TIM pengabdian masyarakat Universitas Mataram 2021 diharapkan mampu menciptakan lingkungan yang bersih dengan memanfaatkan sampah menjadi produk serbaguna.

\section{Metode}

Pada pelaksanaan program kerja pengolahan sampah kelompok TIM pengabdian masyarakat Desa Penimbung 2021 telah terlaksana yaitu Sosialisasi dan pelatihan terkait pengelolaan sampah. Pada program sosialisasi tersebut pemateri diundang langsung dari pihak DLHK dengan narasumber yaitu $\mathrm{Bu}$ Dian. Sosialisasi terkait pengelolahan sampah tersebut dilaksanakan di Kantor Desa Penimbung dengan tetaap menerapkan protocol kesehatan seperti menggunakan masker, menjaga jarak, mencuci tangan dan penyemprotan handsanitizer sebelum masuk ke area sosialisasi. Kegiatan sosialisasi tersebut dilakukan dengan tujuan untuk memberi informasi dan pemahaman kepada warga Desa Penimbung terkait bagaimana bahaya sampah bagi kehidupan kedepannya. Tidak hanya itu, dalam sosialisasi tersebut juga dipaparkan baimana cara pengumpulan dan pengelolaan sampah anorganik untuk dapat diolah menjadi barang yang bersifat ekonomis.

Selain kegiatan sosialisasi terkait pengelolaan sampah, kegiatan lainnya yang dilakukan yaitu mengadakan pelatihan pembuatan Takakura dan Ecobrick. Pelatihan pembuatan Takakura ini dilakukan berdasarkan hasil survei kelompok TIM pengabdian masyarakat Desa Penimbung 2021 mengenai banyaknya jumlah sampah rumah tangga, belum adanya pengelolaan sampah, serta belum adanya pemanfaatan sampah organic rumah tangga sehingga dapat menimbulkan bau yang tidak sedap, dan sebagai media penularan penyakit seperti diare. Takakura ini merupakan salah satu metode yang tepat dan praktis untuk menanggulangi masalah sampah rumah tangga yang terdiri dari sampah organic, yaitu jenis sampah yang dapat terurai oleh bakteri. Kemudian pelatihan pembuatan Kegiatan pelatihan tersebut dilaksanakan di halaman posko TIM pengabdian masyarakat Desa Penimbung yang diisi oleh pemateri yang di undang langsung dari

Bank Sampah NTB, yaitu Bu Aisyah. Kegiatan tersebut dihadiri oleh beberapa warga setempat dan perwakilan remaja-remaji masjid Desa Penimbung sebagai perwakilan dengan tujuan untuk mengurangi kerumunan dan tetap menerapkan protocol kesehatan yang berlaku. 
Kegiatan tersebut juga didukung dengan pembagian secara langsung hasil pembuatan Takakura yang dihasilkan oleh mereka sendiri. Tidak hanya sampai disana, setelah dilakukannya praktik pembuatan dan pembagian Takakura, kelompok TIM pengabdian masyarakat Desa Penimbung tetap melakukan monitoring setiap minggunya untuk mengetahi hasil pembuatan Takakura tersebut berhasil atau tidak digunakan.

Dengan terlaksananya kegiatan tersebut diharapkan warga Desa Penimbung khusunya para ibu rumah tangga mampu mengolah dan memanfaatkan sampah rumah tangga, sehingga setiap rumah tangga mampu berkontribusi dalam mengurangi timbunan sampah di Desa Penimbung.

\section{Hasil dan Pembahasan}

Pelaksanaan TIM pengabdian masyarakat Program Pariwisata dan Lingkungan dilaksanakan sejak bulan Juni 2021 hingga Agustus 2021 di Desa Penimbung, Kecamatan Gunung Sari, Kabupaten Lombok Barat. Pelaksanaan program difokuskan pada program lingkungan yaitu kegiatan pengolahan sampah. Permasalahan sampah merupakan salah satu masalah serius yang sedang dihadapi oleh masyarakat desa Penimbung. Adapun jenis sampah yang sering dijumpai di desa tersebut, antara lain:

a. Sampah Basah (garbage), yaitu sejenis sampah yang terdiri dari barang-barang yang mudah membusuk dan menimbulkan bau yang tidak sedap seperti sampah dapur (sisa sayur atau buah, dan lain- lain).

b. Sampah Kering (rubbish), terdiri dari sampah yang dapat dibakar dan tidak dapat dibakar seperti sampah plastik, sampah sisa kayu.

c. Abu (ashes), yang termasuk sampah ini adalah sisa-sisa dari pembakaran seperti daun atau sampah plastik yang dibakar.

Jenis-jenis sampah diatas sebenarnya dapat diolah kembali untuk mengurangi jumlah sampah yang menumpuk. Oleh karena itu tim TIM pengabdian masyarakat Tematik mengadakan pelatihan mengenai pengolahan sampah. Sebelum diolah, sampah terlebih dahulu dipisahkan antara sampah organik dan anorganik. Dari sampah yang telah dipilah tersebut baru dilakukan pengolahan. Pengolahan sampah yang dilakukan yaitu pengolahan sampah organik dan anorganik.
Pengolahan sampah organik difokuskan pada kegiatan pembuatan kompos Takakura, sedangkan untuk pengolahan sampah anorganik difokuskan pada kegiatan pembuatan Echobrick.

Takakura merupakan metode pengolahan sampah organik yang dipelopori oleh Mr. Koji Takakura, peneliti asal Jepang. Proses pengomposan ala keranjang takakura merupakan proses pengomposan aerob, di mana udara dibutuhkan sebagai asupan penting dalam proses pertumbuhan mikroorganisme yang menguraikan sampah menjadi kompos (Kurniati, 2013). Media yang dibutuhkan dalam proses pengomposan yaitu dengan menggunakan keranjang berlubang, diisi dengan bahan-bahan yang dapat memberikan kenyamanan bagi mikroorganisme. Proses pengomposan metode ini dilakukan dengan cara memasukkan sampah organic (idealnya sampah organik tercacah) ke dalam keranjang setiap harinya dan kemudian dilakukan kontrol suhu dengan cara pengadukan dan penyiraman air. Pembuatan kompos Takakura ini sangat cocok dilakukan dirumah karena setiap hari masingmasing rumah menghasilkan limbah dapur yang dimana limbah inilah yang dapat dijadikan bahan pembuatan

kompos Takakura. Kelebihan membuat kompos dengan metode Takakura diantaranya (1) pembuatannya lebih sederhana atau praktis. (2) Biaya yang dibutuhkan tidak mahal. (3) Bahanbahan mudah diperoleh di lingkungan. (4) Mudah dipindahkan dan bisa ditempatkan dimana saja. (5) Meningkatkan nilai ekonomis sampah organik. (6) Hemat biaya dan waktu.

Sebelum membuat kompos, terlebih dahulu kita harus membuat cairan fermentasi sebagai bioaktifator. Untuk membuat cairan fermentasi, maka disini kita meyiapkan 2 jenis larutan, yaitu larutan A dan larutan B. Alat dan bahan yang dibutuhkan untuk larutan A adalah botol bekas, gula, tempe, ragi, yakult, tape (minimal 3 jenis). Cara membuatnya; (1) Menuang air ke dalam botol secukupnya (jangan terlalu penuh). (2) Memasukkan gula kedalam air tersebut semanisnya. (3) Memasukkan tempe, tape, ragi, dan yakult kedalam larutan gula lalu dikocok kembali. (4) Menutup botol yang telah berisi bahan- bahan fermentasi. Alat dan bahan yang dibutuhkan untuk larutan B adalah botol bekas, garam, kulit buah dan kulit sayur (minimal 3 jenis). Cara membuatnya; (1) Menuang air ke dalam botol secukupnya 
(jangan terlalu penuh). (2) Memasukkan garam kedalam air tersebut seasinnya. (3) Memasukkan tkulit buah dan sisa sayuran lalu dikocok kembali. (4) Menutup botol yang telah berisi bahan-bahan fermentasi. Setelah kedua larutan dibuat maka ditempatkan ditempat yang sejuk dan didiamkan selama 3 hari. Selama 3 hari usahakan penutup botol dibuka sebentar lalu ditutup kembali untuk mengeluarkan gan dan memberi udara pada biang bakteri.

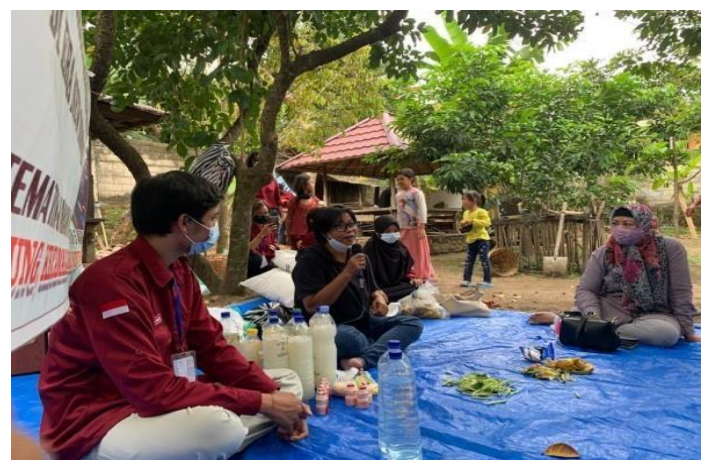

Gambar 1. pembuatan cairan fermentasi

Setelah 3 hari maka dibuat TPB (Tempat Pembiakan Bakteri). Alat dan bahan yang dibutuhkan disini yaitu keranjang yang sudah dilapisi karung bekas, dedak, sekam, dan tanah. Prosedurnya; (1) Mengaduk rata sekam, dedak, dan tanah. (2) Menuang cairan fermentasi A dan B ke campuran sekam, dedak dan tanah tadi. (3) Mengaduk hingga rata (pastikan jangan terlalu kering atau terlalu basah). (4) Menutup TPB dengan karung bekas. Setelah 3 hari maka akan tumbuh jamur dipermukaan TPB dan artinya proses pengomposan sudah bisa dimulai. Prosesnya sangat sederhana yaitu dengan memasukkan sampah organik setiap harinya kedalam TPB dengan perbandingan 80 TPB 20 sampah organik hingga keranjang penuh. Apabila keranjang sudah penuh, kira-kira $90 \%$ sudah terisi, ambil dua pertiganya. Pindahkan kompos tersebut kedalam karung, biarkan selama 2 minggu sebelum digunakan. Kompos yang dihasilkan kering tidak terdapat cairan. Kompos takakura sudah terbentuk sempurna apabila teksturnya sudah seperti tanah, warna coklat kehitaman, tidak berbau.

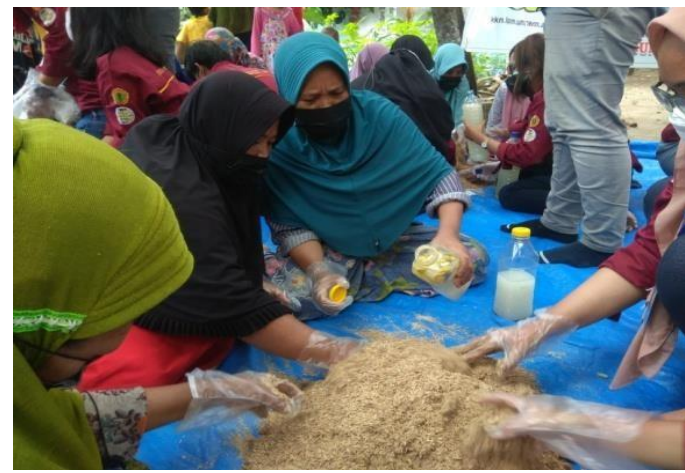

Gambar 2 Pencampuran Cairan fermentasi

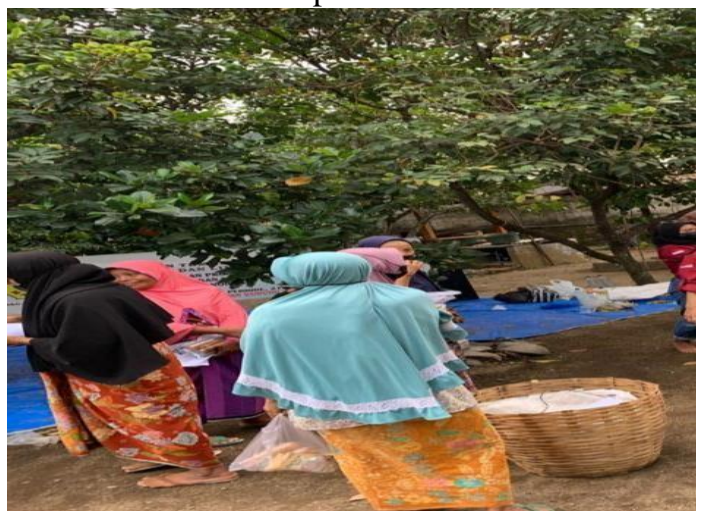

Gambar 3. menutup kompos dengan karung

Adapun pengolahan sampah anorganik pengolahannya difokuskan menjadi ecobrik. Ecobrik sendiri merupakan penanganan sampah plastik dengan cara menjebak plastik agar tak berkeliaran di lingkungan. Fungsi ecobrik sendiri bukan untuk menghancurkan sampah plastik, melainkan untuk memperpanjang usia plastikplastik tersebut dan mengolahnya menjadi sesuatu yang berguna, yang bisa dipergunakan bagi kepentingan manusia pada umumnya (Suminto,2017). Hal sederhana yang dilakukan pada teknik ini adalah mengisi botol plastik secara padat dengan plastik.

Manfaat ecobrik sangat beragam mulai dari mengurangi limbah plastic dengan pengolahannya, Ecobrick digunakan untuk membuat furniture, taman dan bangunan. Furniture dan bangunan yang terbuat dari ecobricks tidak mudah rusak karena terbuat dari plastik yang akan terurai selama 300 tahun dan dapat digunakan kembali, Ecobricks memiliki kemampuan konstruksi yang baik dan hemat biaya, Mengurangi penggunaan semen atau kayu dalam konstruksi bangunan, Rumah yang terbuat dari ecobricks tetap hangat ketika udara di luar dingin dan tetap dingin selama musim panas dan Penciptaan kegiatan dengan memanfaatkan 
ecobricks seperti menghias atau membentuknya menjadi mainan atau boneka dapat memengaruhi keterampilan motorik halus anak.

Bahan yang dibutuhkan dalam pembuatan ecobrik berupa (1) Botol Plastik $500 \mathrm{ml}$ (untuk wadah) (2) Sampah plastik (3) Kayu. Cara pembuatan ecobrik : (1) Cuci dan sterilkan semua elemen plastik maupun perlengkapan menggunakan sabun anti bakteri. Pensterilan elemen-elemen plastik sangat diperlukan untuk menghilangkan bakteri yang melekat (2) Keringkan semuanya menggunakan lap bersih (3) Masukkan sampah plastik yang Anda miliki kedalam botol tersebut. Jika sampah plastik berukuran besar, potong menggunakan gunting (4) Padatkan sampah plastik menggunakan ujung bawah sendok ke seluruh ruangan botol. Jangan sampai kempes atau mengeluarkan bunyi jika ditekan dari luar (5) Tutup botol tersebut dan satu buah ecobrik selesai.
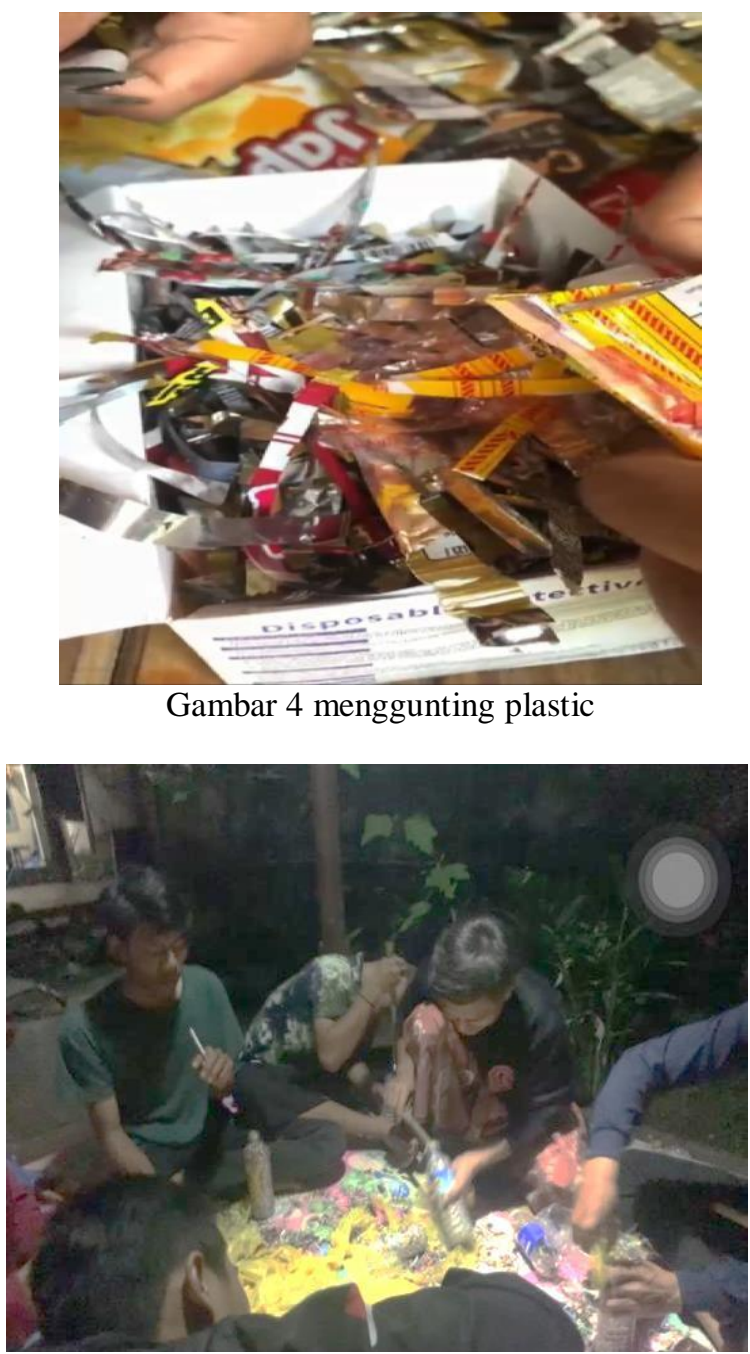

Gambar 5 memasukkan plastik kedalam botol

\section{Kesimpulan}

Pembuatan kompos Takakura dan ecobrik dengan memanfaatkan limbah rumah tangga memberikan manfaat yang besar bagi masyarakat Desa Penimbung, khususnya warga dusun Penimbung Timur. Selain meminimalisir jumlah sampah, Kompos Takakura dan ecobrik mempunyai nilai praktis dan nilai ekonomis, sehingga masyarakat Desa Penimbung bisa mengambil manfaat yang banyak dari hasil pengolahan sampah ini.

\section{Daftar Pustaka}

Lenkiewicz, Z., \& Webster, M. (2017). Making Waste Work: A Toolkit How to turn mixed plastic waste and bottles into ecobrick A step-by-step guide. UK: CIWM

Suminto, Sekartaji. 2017. Ecobrick: solusi cerdas dan kreatif untuk mengatasi sampah plastik. Jurnal Desain Produk (Pengetahuan dan Perancangan Produk). Vol.3 (1 ). 27- 35.

Tamyiz, M. dkk . (2018). Pelatihan Pengomposan dengan Sistem Takakura pada Siswa MA Darul Ulum Waru. Vol.1 (1).

Publica Health. (2019). Pelatihan pembuatan Pupuk Kompos Takakura guna memanfaatkan Sampah Organik Rumah Tangga. Diakses pada 9 Agustus 2021, dari http://www.phcyber.com/2019/02/pelatihan-pembuatan- pupukkompos.html?m=1 